\title{
PANDANGAN ULAMA TENTANG KEPEMIMPINAN DALAM NEGARA ISLAM
}

\author{
Arsyad Sobby Kesuma*
}

\begin{abstract}
A bstract: The idea of Islamic state and leadership has long been a subject of debate. But it remains intriguing to ask once and again what does Islamic state mean and what is its real and true nature? What does leadership mean and does Islam really need politics? This paper is designed mainly to answer these important questions. It will trace the ideal form of politics in Islam by investigating the formulas promulgated by the ulama over centuries. Two notions will be the focus of this investigation. First is the notion of how a leader should be elected, and second is the problem of what are the conditions of the leader. These two interrelated problems are at the centre of the idea of leadership in Islam. We argue that by understanding them one would necessarily be able to grasp the "Islamic" formula of statehood and politics.
\end{abstract}

Keywords: Islamic state, leadership, politics

\section{Pendahuluan}

Perkara yang paling asasi ditekankan oleh al-Qur'an dan al-Sunnah dalam proses mewujudkan dan melahirkan pemerintahan Islam adalah "soal kepemimpinan". Karena begitu pentingnya masalah ini sehingga para ulama -baik yang klasik maupun modern merasa perlu menulis secara khusus tema ini dalam berbagai karyanya. Hal ini misalnya sebagaimana diungkapkan oleh al-Shahrastani>la mengatakan: "permasalahan yang paling besar berlaku di kalangan umat Islam adalah tentang kepemimpinan (al-Imamah). Tidak pernah berlaku dalam zaman manapun, peperangan yang lebih besar di kalangan umat Islam dari pada yang berlaku karena masalah kepemimpinan." ${ }^{1}$

Begitu pentingnya masalah kepemimpinan sehingga dalam al-Qur'an, Allah mewajibkan akan kepatuhan terhadap pemimpin. Sebagaimana diungkapkan dalam al-Qur'an: "Hai orangorang yang beriman, taatilah Allâh dan taatilah Rasul (Nya), dan ulil amri di antara kamu. Kemudian jika kamu berlainan pendapattentang sesuatu, maka kembalikanlah ia kepada Allah (al- Qur'an) dan Rasul (sunnahnya), jika kamu benar-benar beriman kepada Allâh dan hari kemudian. Yang demikian itu lebih utama (bagimu) dan lebih baik akibatnya." (QS: al-Nisas: 4: 59).

Bahkan dalam $\mathrm{H}$ dith-pun Rasulullah menekankan akan pentingnya peran pemimpin walau dalam keadaan apapun: Dari Abdullah bin Umar, Rasulullah saw bersabda: Tidak halal bagi tiap orang yang berada di bumi yang terpencil kecuali mereka melantik salah seorang daripada mereka sebagai ketua mereka. (HR: Ahmad Ibn Hambal). ${ }^{2}$ Dalam H dith yang lain: Dari Abu Sa'id al-Khudri, Rasulullah saw bersabda: Apabila kedua orang keluar bermusafir,

\footnotetext{
* IAIN Raden Intan Bandar Lampung

1al-Shahrastani>al-Milalwwa al-Nihal>(Kairo: al-Azhar, jil 1, t,t.), 20.

${ }^{2}$ Ahmad bin $\mathrm{H}$ anbal, Musnad Ibn Hanbal (Beirut: Dasal-Fikr, J ilid 2, t.t.), 177.
} 
salah seorang daripada mereka hendaklah dijadikan ketua. (HR: Abu Daud). ${ }^{3}$

Permasalahan sengketa seputar konsep kepemimpinan dalam negara pertama kali dipicu oleh adanya ketidakjelasan tentang siapa yang pantas menjadi pengganti Nabi Muhł̧mmad Saw dalam mengurusi negara. Dalam hal ini, sedikitnya ada dua kubu besar yang berbeda pendapat tentang hal ini yakni persepsi kalangan Shi sah dan Sunni>Kalangan Shi `ah meyakini bahwa ketika Nabi masih hidup sebenarnya ia telah menunjuk 'Alixa sebagai penggantinya. Berbeda dengan kalangan Shi $̧$ h, kalangan Sunniæmengatakan bahwa pernyataan kalangan Shi ah tersebut tidak masuk akal dan bertentangan dengan realita sejarah.

Tulisan ini bertujuan menyajikan uraian seputar perbincangan konsep kepemimpinan negara Islam di antara para intelektual muslim yang tersaji dalam karya-karyanya. Untuk memetakan konsep tersebut, penulis menyajikan dua tema pokok: Pertama, bagaimana respon intelektual muslim terhadap cara pemilihan seorang pemimpin negara?. Kedua, bagaimana kriteria yang harus dimiliki oleh seorang pemimpin negara?.

\section{Cara Pemilihan Kepala Negara}

J ika kita merujuk pada khazanah kekayaan intelektual muslim - baik yang klasik maupun yang modern, kajian seputar cara pemilihan atau pengangkatan seorang kepala negara sangatlah beragam. Tema ini adalah satu di antara tema yang paling penting di dalam memperbincangkan konsep sebuah negara Islam.

Di antara para intelektual muslim yang menyajikan tema ini dengan cukup jelas adalah alBaqillani>Ulama yang satu ini dikenal sebagai ulama yang mewakili kalangan ulama Sunni> Pemikiran-pemikiran yang dicetuskan olehnya kerapkali bertentangan bahkan terkesan membantah pernyataan kalangan Shi ̧ah. Di antara buah pemikiran yang cenderung mengkritik pemikiran atau doktrin Shi sah adalah; Ia mengatakan bahwa tidak ada orang yang mengetahui tentang penunjukan 'Aliøleh Nabi untuk memangku jabatan imam. la juga mengatakan bahwa terpilihnya AbußBakar sebagai pengganti Nabi untuk menjadi Khalifah di pertemuan Thaqifah Bani Sa'idah adalah merupakan konsensus umat Islam, karena itu, kepercayaan kalangan Shisah sebagai suatu hal yang palsu. ${ }^{4}$

Atas dasar itu, maka al-B aqillaniæmenetapkan bahwa pemilihan seorang pemimpin adalah melalui pemilihan (al-Ikhtiyan) oleh Ahl al-H fall wa al-'Aqd. Menurutnya pemilihan pemimpin akan dikatakan sah meskipun dilakukan oleh seorang dari Ahl al-H falll wa al-'Aqd. Setelah kepala negara terpilih, maka seluruh kaum Muslimin harus hadir untuk memberikan bay'ah kepada imam yang terpilih tersebut. ${ }^{5}$

Lebih lanjut ia menyatakan penolakan terhadap adanya dualisme atau lebih kepemimpinan dalam satu masa. Pendapatnya ini menurut J. Suyuthi Pulungan adalah bentuk penolakan terhadap keabsahan klaim Fatimiyah yang Shi ah dan daulah U mayah yang merupakan rival Abasiyah di Spanyol. Menurutnya, meskipun umat Islam telah terpecah ke dalam berbagai aliran dan masing-masing mengklaim berhak mempunyai pemerintahan sendiri,

\footnotetext{
${ }^{3}$ Abuæawud, Sunan Abi®awud (Beirut: Mu'assasah al-Kutub al-Thaqafiyah, J il. 1, 1988), 42.

${ }^{4}$ Dikutip oleh Muhąmmad Yusuf Musa>Nizam al-H ukm fi al-Islam, 74.

${ }^{5} \mathrm{~J}$. Suyuthi Pulungan, Fiqh Siyasah, 242.
} 
akan tetapi tetap tidak bisa dibenarkan. Kepala negara yang sah adalah yang dahulu diangkat. Bila kemudian ada yang mendirikan pemerintahan lain, maka ia wajib diperangi. ${ }^{6}$

Pendapat yang menarik tentang mekanisme pengangkatan pemimpin negara diungkapkan oleh al-Baghdadi. la mengatakan bahwa sebenarnya tidak ada kesepakatan atau pendapat tentang tata cara pengangkatan kepala negara; apakah dengan sistem penunjukan atau pemilihan. Akan tetapi, pada umumnya kelompok Sunni, termasuk Mu'tazilah dan Khawasij, menetapkan dengan cara pemilihan. $\mathrm{Hal}$ ini dilakukan dengan cara ijtihad yang bertanggung jawab oleh mereka yang memenuhi syarat melakukannya. Meskipun begitu, menurut alBaghdadi, dengan cara penunjukan pun masih dibolehkan. ${ }^{7}$

Ulama klasik lain yang juga menguraikan masalah kepemimpinan adalah al-Mawardi> dalam kitabnya al-Ahkam al-Sultąniłah, Abu Ya'la dalam kitabnya al-Ahkam al-Sultăniyah, Ibn Taymiyah dalam kitabnya al-Siyasah al-Shar'iyah.

Sedangkan ulama dari kalangan modern yang cukup jelas membicarakan persoalan tata cara pemilihan pemimpin negara di antaranya adalah al-Maududi. Dalam hal ini ia mengatakan bahwa hakim sebenarnya adalah Allah. Menurutnya, J ika diamati realisasi pelaksanaan konsep kehakiman yang fundamental dalam bumi kaum Muslimin, maka akan diketahui kedudukannya tak lebih hanya sebagai wakil Tuhan. Pendapat al-Maududi ini didasari dari pemahamannya atas al-Q ur'an (QS: al-Nur: 24: 55). ${ }^{8}$

Ayat di atas menururtal-Maududi menjelaskan teori negara dalam pandangan Islam. Dalam teori tersebut Allah mengemukakan dua konsep makro atau dua prinsip mendasar: ${ }^{9}$ Pertama, dalam kepemimpinan Islam digunakan terminologi khilafah. Yang menarik dari pemikiran alMaududi adalah elaborasi atas beberapa istilah terkait dengan kepemimpinan. Dalam hal kepemimpinan dalam Islam, al-Maududi memakai istilah khilafah sebagai pengganti istilah $\mathrm{H}$ glkimiyah. Menurutnya, istilah hłkim hanyalah untuk Allah. Oleh karena itu setiap penguasa di bumi, meskipun di bawah undang-undang Islam, untuk selanjutnya disebut khalifah (wakil). Hakim Tertinggi yakni Allah. Peran khalifah di bumi berada di bawah kendali Allah karena tidak seorang pun menguasainya, kecuali Allah. Kedua, Allah telah menjanjikan orang-orang yang mukmin tentang pengangkatan khalifah, tetapi Dia tidak mengatakan hendak mengangkat seorang khalifah dari salah satu di antara mereka.

Secara eksplisit menurut al-Maududi hal ini menunjukkan bahwa seluruh mukmin adalah khalifah Allah. Mereka bertanggung jawab kepada Allah dalam kaitannya sebagai khalifah. Seperti yang disabdakan oleh Nabi Muhł̆mmad saw: “Tiap-tiap kamu adalah pemimpin dan

\footnotetext{
${ }^{6} \mathrm{~J}$. Suyuthi Pulungan, Fiqh Siyasah, 243.

7 Dukutip dari Ann KS Lambton, State and Government, 81.

${ }^{8}$ Artinya: "Dan Allâh telah berjanji kepada orang-orang yang beriman di antara kamu dan mengerjakan amal-amal yang saleh bahwa Dia sungguh- sungguh akan menjadikan mereka berkuasa dimuka bumi, sebagaimana Dia telah menjadikan orang-orang sebelum mereka berkuasa, dan sungguh Dia akan meneguhkan bagi mereka agama yang telah diridhai-Nya untuk mereka, dan Dia benar-benar akan menukar (keadaan) mereka, sesudah mereka dalam ketakutan menjadi aman sentausa. Mereka tetap menyembahku-Ku dengan tiada mempersekutukan sesuatu apapun dengan Aku. Dan barangsiapa yang (tetap) kafir sesudah (janji) itu, maka mereka itulah orang-orang yang fasik". (QS : al-Nus: 24: 55).

${ }_{9}^{9}$ A bu ral-A'la al-Maududi, Tafhim al-Q ur'an (The Meaning of The Q ur'an), Vol. viii., 158-159. atau lihat penafsiran yang sama dalam buku Abu al-A'la al-Maududi, Politik Alternatif, 57.
} 
bertanggung jawab terhadap yang dipimpinnya, seorang kepala negara yang memimpin rakyat bertanggung jawab atas mereka, dan seorang laki-laki adalah pemimpin penghuni rumahnya dan bertanggung jawab atas mereka ". (HR. Muttafaq 'alayh). ${ }^{10}$

$\mathrm{H}$ dith ini dipahami oleh al-Maududi bahwa masing-masing manusia mempunyai peluang dan kedudukan yang sama dan tidak ada perbedaan untuk menjadi seorang khalifah di muka bumi ini. Menurut al-Maududi dalam negara Islam, pemerintahan dibentuk secara demokratis dan diselenggarakan berdasarkan konsultasi timbal balik sebagaimana diisyaratkan dalam alQur'an (QS: al-Nus24: 55).

Dengan sandaran ayatdi atas, al-Maududi mengatakan bahwa kekhalifahan yang dijanjikan oleh Allah bersifat universal dan tidak terbatas hanya pada individu atau sekelompok orang. J ika melihat pendapat al-Maududi di atas, hampir sama dengan doktrin Khawarij yang mengatakan bahwa setiap Muslim dari kalangan manapun berhak untuk menjadi kepala negara.

Dalam mekanisme pengangkatan seorang pemimpin negara, al-Maududi mencontoh apa yang telah diperaktekkan pada masa Khulafasal-Rashidin yang melakukan model pemilihan secara terbuka. Model pengangkatan pemimpin negara pada masa Khulafasal-Rashidin adalah model pemilihan yang paling ideal. Realita sejarah pada masa Khulafas al-Rashidin oleh alMaududi digunakan untuk merumuskan mekanisme pemilihan kepala negara yang menurutnya sesuai dengan ajaran Islam sebagai berikut; Pertama, dalam negara Islam, pemilihan kepala negara sepenuhnya bergantung kepada masyarakat umum, dan tidak seorang pun berhak untuk mengangkat diri dengan paksaan atau kekerasan sebagai Amir. Kedua, tidak ada satu klan atau suatu kelompok pun yang memonopoli jabatan. Ketiga, pemilihan harus dilaksanakan dengan prinsip kehendak bebas kaum Muslim dan tanpa adanya pemaksaan atau ancaman. ${ }^{11}$

Menarik membicarakan poin nomor pertama di atas yang mengatakan bahwa seorang pemimpin tidak boleh mencalonkan dirinya sendiri. Al-Maududi mengatakan bahwa dalam Islam tidak ada arena buat pencalonan atau perebutan kedudukan, apalagi dengan menggunakan kampanye-kampanye pemilihan. $\mathrm{H}$ al ini tidak sesuai dengan pemikiran dan pandangan Islam. Tidak hanya itu, al-Maududi melengkapinya dengan konsekuensi hukum jika terjadi hal di atas yakni perebutan kekuasaan. Menurutnya jika di negara Islam ditemukan orang yang melakukan praktek semacam itu, maka ia akan dibawa ke meja hijau dan akan menerima hukuman yang berat. ${ }^{12}$ Konsep yang ditawarkan oleh al-Maududi ini terlihat sangat utopis dan tidak realistis bahkan di negara Pakistan saat itu yang sudah memakai sistem kepartaian yang memilih kepala negara dengan sistem pencalonan.

Mencermati mekanisme cara pemilihan kepala negara di atas, pemikiran al-Maududi ini betul-betul sesuai dengan apa yang disuarakan oleh konsep demokrasi yang memberikan kesempatan kepada siapa pun untuk menduduki jabatan kepala negara. Pemikiran al-Maududi di atas memberikan kesempatan kepada siapa pun untuk menjadi khalifah, meskipun begitu, ia menentukan kriteria-kriteria bagi siapa yang menghendaki menjadi pemimpin negara. Kriteria

\footnotetext{
${ }^{10} \mathrm{Ahmad}$ bin Hanbâl, Musnad bin Hanbal, J ilid. II, 5 dan 54.

${ }^{11} \mathrm{~A}$ bu al-A'la al-Maududi, The Islamic Law and Constitution, 258-259.

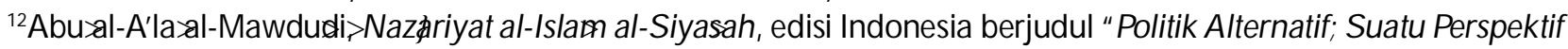
Islam", Penj. Moh Nurhakim (J akarta: Gema Insani Press, 1991), 69.
} 
yang ditetapkan oleh al-Maududi pada akhirnya justru memosisikan al-Maududi bukan sebagai seorang yang sesuai dengan demokratis, akan tetapi sebaliknya, ia justru terjebak kepada halhal yang mendekati prilaku diskriminatif. Untuk lebih jelas pemikiran al-Maududi mengenai kepala negara akan diuraikan mengenai kriteria pemimpin negara, di bawah ini.

\section{Kriteria Pemimpin Negara Islam}

Masalah pelik lainnya terkait dengan konsep kepemimpinan negara dalam Islam adalah perbincangan seputar kriteria seorang pemimpin negara Islam. Di antara ulama yang serius mengulas tema ini adalah lagi-lagi al-Bâqillânî salah seorang ulama Sunni. Dalam hal ini ia mengatakan bahwa syarat kepala negara haruslah berilmu pengetahuan yang luas. $\mathrm{Hal}$ ini sangat diperlukan karena dengan pengetahuan yang luas ia akan dapat melihat apakah keputusan yang diambil oleh hakim negara sesuai dengan sharish atau tidak. Syarat seorang kepala negara lainnya adalah harus mempunyai sifat adil dalam segala urusan, berani dalam peperangan, dan bijaksana dalam mengorganisir militer yang bertugas melindungi rakyat dari gangguan musuh. Di samping syarat di atas, al-Baqillani»mengatakan bahwa syarat kepala negara haruslah dari suku Quraysh. ${ }^{13}$ MenurutJ . Suyuthi Pulungan bahwa persyaratan yang terakhir di atas adalah bentuk penolakan al-B aqillaaiłerhadap doktrin Khawasij yang mengatakan bahwa setiap Muslim dari kalangan manapun berhak untuk menjadi kepala negara, di samping penolakannya terhadap Shiæah yang mengatakan bahwa kepala negara terbatas pada keturunan 'Ali ${ }^{4}$

Hampir sama dengan apa yang diungkapkan oleh al-Baqillani>di atas, al-Baghdadi mengatakan bahwa syarat seorang kepala negara adalah: Pertama, berilmu pengetahuan, syarat ini diperlukan untuk dapat mengetahui apakah undang-undang yang telah dibuat oleh para mujtahid sesuai dengan hukum agama. Kedua, bertindak adil dalam menjalankan segala tugas pemerintahan dan tugas administrasi. Ketiga, bersifat jujur dan słleh. Keempat, berasal dari suku Quraysh. ${ }^{15}$

Berbeda dengan kedua ulama di atas, Ibn Abi Rabi' menentukan syarat-syarat kepala negara dengan lebih melihat dari sisi kekuatan dan keturunan sebagai berikut: pertama, kebapaan dan berasal dari keluarga raja; Kedua, bercita-cita besar, cita-cita ini bisa diperoleh dari pendidikan dan akhlaq; Ketiga, berpandangan kokoh. Sifat ini dapat diperoleh dengan meneliti dan mempelajari kehidupan orang terdahulu dan pengalamanan hidup mereka; Keempat, tangguh dalam menghadapi kesukaran dengan keberanian dan kekuatan; Kelima, memiliki harta banyak; Keenam, memiliki pembantu-pembantu dengan loyalitas tinggi. ${ }^{16}$

Berbeda dengan beberapa pandangan ulama di atas, Imam al-J uwaini mensyaratkan kepala negara dengan menitikberatkan pada sisi kemampuan berfikir. Pola berfikir yang diajukan oleh al-J uwaini hampir sama dengan apa yang digagas oleh Plato dahulu. Imam al-J uwaini mengatakan bahwa pemimpin negara haruslah seorang mujtahid, sehingga dengan begitu, ia

${ }^{13}$ Dikuti dari Ann K.S. Lambton, State and Government, 76-77.

${ }^{14} \mathrm{~J}$. Suyuthi Pulungan, Figh Siyasah, 253.

${ }^{15}$ Dikutip dari Ann KS Lambton, State and Government, 79-80.

${ }^{16}$ Dikutip dari M uhammad J alabSharaf dan 'Ali>A bd al-Mu'tiß\$ uhłmmad, al-Fikr al-Siyasi fi al-Islam (Iskandariyat: Daral-J ami'at al-Misijiyah, 1978), 219. 
tidak butuh meminta fatwa kepada orang lain, mempunyai kemampuan untuk mengurusi kemaslahatan dan dapat memeliharanya, mempunyai kemampuan dalam mengatur militer untuk pertahanan, memiliki wawasan yang luas dalam memikirkan kaum Muslimin, memiliki sifat lemah lembut, tegas dalam menjalankan hukum, seorang laki-laki yang merdeka. Yang menarik dari al-J uwaini adalah ia tidak menetapkan syarat seorang pemimpin negara dari keturunan Quraysh. Hal tersebut menurutnya merupakan suatu masalah yang diperselisihkan yang tidak boleh membuat statemen yang pasti dan mutlak. ${ }^{17}$

Berbeda dengan gurunya di atas, al-G hazalixdalam hal penentuan syarat untuk menjadi seorang pemimpin negara, mengajukan sepuluh syarat yang harus dipenuhi: haruslah seorang laki-laki, sehat pendengaran dan penglihatan, merdeka, sehat, punya kekuasaan nyata, memiliki kemampuan, wara', berilmu, dan haruslah bersuku Quraysh. ${ }^{18}$

Hampir sama dengan Imam al-J uwaini di atas, Ibn Khaldun mengatakan bahwa syarat seorang pemimpin negara haruslah memenuhi lima syarat; pertama, berilmu pengetahuan, dengan ilmu pengetahuan menurutnya ia dapat melaksanakan hukum-hukum Allah dan sanggup membuat keputusan yang bebas dengan jalan ijtihad. Kedua, al-Kifayah, yakni kesanggupan melaksanakan hukuman-hukuman yang telah ditetapkan oleh undang-undang. Ketiga, berlaku adil. $\mathrm{H}$ al ini diperlukan karena imamah adalah suatu lembaga keagamaan yang mengawasi lembaga lainnya yang pelaksanaannya membutuhkan keadilan. Keempat, sehat panca indra, dan Kelima, keturunan Quraysh.

Menarik mencermati poin kelima yang disyaratkan oleh Ibn Khaldun di atas, ia menjelaskan sisi rasionalitas mengapa Nabi sampai mengatakan bahwa orang Quraysh-lah yang berhak menjadi pemimpin. Penetapan Nabi tersebut menurut Ibn Khaldun karena pada masa itu, suku Quraysh-lah yang lebih kuat di antara suku-suku lainnya yang ada di Arab pada waktu itu. Di samping itu, suku Quraysh lebih tangguh dan terkemuka dibandingkan suku-suku lainnya. Mereka juga memiliki solidaritas yang tinggi dan memelihara kesatuan umat Islam. Meskipun begitu, menurut Ibn Khaldun apabila dikemudian hari ada suku lain yang ternyata lebih mampu memegang kekuasaan, maka ia pun berhak untuk memimpin. ${ }^{19} \mathrm{Ibn}$ Khaldun nampaknya sadar bahwa kewibawaan suku Quraysh akan berakhir pada suatu masa. Maka persyaratan itu dicantumkan secara simbolis. Dengan demikian, persyaratan kelima yang dinyatakan oleh Ibn Khaldun tentang keharusan dari suku Quraysh tidaklah mutlak.

Menurut Ibn Taymiyah, bahwa orang yang pantas untuk menjadi pemimpin adalah harus mempunyai kualifikasi kekuatan dan integritas. $\mathrm{Hal}$ ini didasarkan atas petunjuk al-Qur'an surat al-Qasłs,\} ayat 26, yang mengatakan bahwa orang yang terbaik untuk bekerja adalah orang yang kuat lagi dipercaya (amanah). ${ }^{20}$ Dalam hal syarat menjadi seorang pemimpin, Ibn Taymiyah tidak mensyaratkan harus dari suku Quraysh. Hal ini menurutnya bahwa pernyataan itu adalah permasalahan yang diperselisihkan oleh kalangan ulama, maka syarat itu tidak mungkin ditetapkan. Bahkan menurutnya, pendapat bahwa harus dari suku Quraysh adalah pendapat

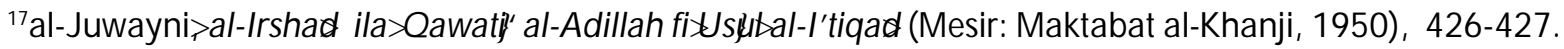

${ }^{18} \mathrm{~J}$. Suyuthi Pulungan, Fiqh Siyasah, 256.

${ }_{19}$ Ibn Khaldun, Muqaddimah, 193-194.

${ }^{20}$ Ibn Taymiyah, al-Siyasah al-Shar'iyah fí łslah al-Ra'y wa al-Ra'łyat((B eirut: Dasal-Kutub al-'Arabiyat, 1966), 15.
} 
yang bertentangan dengan konsep persamaan yang digagas oleh al-Qur'an sendiri dalam surat al-H ujurat ayat 13. J adi, meskipun pendapat itu berdasarkan hłdith, akan tetapi bertentangan dengan nash al-Qur'an sendiri. ${ }^{21}$

Al-Mawardiðdalam kitab Adab al-Dunya mengatakan bahwa seorang pemimpin negara haruslah mempunyai syarat-syarat sebagai berikut:22 Pertama, bersifat adil (al-'adalah). Masalah adil ini bagi al-Mawardiæadalah masalah yang sangat fundamental. Tanpa persyaratan ini, proses yang baik dalam kepemimpinan negara sulit terlaksana. Lebih jauh, ia mensinyalir, sifat adil ini pertama akan tercermin dalam tingkat pribadi pada sikap senang melakukan semua perbuatan yang baik dan segan mengerjakan perbuatan yang keji. Apabila keadilan itu sudah mampu digelar pada level individu, maka sangat mungkin ia mampu menegakkan keadilan di tingkat sosial dan masyarakat. la akan mampu menghadapi aneka ragam kelompok masyarakat manusia atas prinsip pemerataan dan persamaan. Dengan kata lain, dalam konteks sosial kemasyarakatan, keadilan seorang kepala negara berarti keserasian sosial kemasyarakatan; keadilan kepala negara berarti keserasian dan keseimbangannya dalam mengusahakan kesejahteraan dan kebahagiaan warga negara dengan perlakuan-perlakuan yang berdimensikan keadilan. Kedua, berpengetahuan (al-'alim). Kapasitas pengetahuan yang luas ini dibutuhkan untuk menopang kemampuannya dalam berjihad, berfikir secara independent, yang diperlukan setiap saat oleh seorang kepala negara. Dalam proses pengambilan keputusan dan kebijaksanaan, ijtihad seorang kepala negara mutlak diperlukan. J ika seorang kepala negara tidak memiliki wawasan yang cukup, dikhawatirkan ia akan dengan mudah mengabaikan nilai-nilai keagamaan dalam kehidupan pemerintahannya, yang pada gilirannya akan mengarah pada penanganan masalahmasalah kenegaraan secara serampangan. Ketiga, memiliki kemampuan mendengar, melihat dan berbicara secara sempurna. Kemampuan ini sangat berguna untuk dapat mengenali masalah dengan teliti dan dapat mengkomunikasikannya dengan baik dalam proses penentuan hukum. Keempat, mempunyai kondisi fisik yang sehat yang menjamin pergerakan tubuhnya secara bebas. Kelima, memiliki kebijakan dan wawasan yang memadai untuk mengatur kehidupan rakyat dan mengatur kepentingan umum. Keenam, memiliki keberanian untuk melindungi wilayah kekuasaan Islam dan untuk mempertahankannya dari serangan musuh. Ketujuh, berasal dari keturunan Quraysh. Pernyataan ini menurut al-Mawardiłordasarkan ketentuan yang disepakati umum.

Menurut Muhł̧mmad AbuZahrah untuk terciptanya kekhalifahan yang bersifat kenabian dan tidak berubah menjadi kerajaan turun-temurun. J umhur ulama menurutnya bersepakat menetapkan empat syarat bagi seseorang yang akan diangkat menjadi imam: Pertama, seorang pemimpin haruslah berasal dari suku Quraysh. Kedua, adanya bay'ah dari Ahl al-H all wa al'Aqd (wakil rakyat). Dalam hal ini antara wakil rakyat, tentara, serta mayoritas kaum Muslim menyatakan janji setia kepada seorang khalifah untuk mematuhi dan mentaatinya, baik dalam hal yang menyenangkan maupun yang tidak menyenangkan, selama tidak dalam kerangka kedurhakaan kepada Tuhan. Di samping itu, khalifah juga harus berjanji kepada rakyatnya akan

${ }^{21}$ Qamaruddin Khan, Pemikiran Politik Ibn Taimiyah, penj. Anas Mahyuddin (Bandung: Pustaka, 1983), 249.

${ }^{22}$ Abû Hasan al-Mawardi>Adab al-Dunya wa al-Din, tahø̧iø;; Abd al-Satar A hinad Faraj (Beirut: Alam Kutub, t.t.), 6. 
melaksanakan hukum dan kewajiban serta berlaku adil berdesarkan petunjuk al-Qur'an dan Sunnah Nabi. Ketiga, Musyawarah, proses pemilihan seorang khalifah haruslah dengan jalan musyawarah. Keempat, keadilan, syarat keadilan juga harus terpatri pada pribadi seorang imam, tidak memprioritaskan keluarganya, tidak mengangkat seorang karena hawa nafsu, tidak mengutamakan orang yang disenangi, dan tidak menyingkirkan orang yang dibenci. ${ }^{23}$ Lebih lanjut Abu>Zahrah mengatakan bahwa jika seorang pemimpin tidak memiliki kualifikasi sebagaimana disebutkan di atas, maka sistem kepemimpinannya bukan sistem kepemimpinan model Islam akan tetapi bersistem sekuler. ${ }^{24}$

Pendapat yang tidak kalah menariknya - bahkan unik sehingga perlu untuk didiskusikan adalah yang datang dari al-Maududi. Dalam uraiannya seputar kriteria seorang pemimpin negara ia mensyaratkan sebagai berikut: Pertama, ia harus seorang Muslim, kriteria ini menurutnya sesuai dengan firman Allah dalam al-Qur'an. ${ }^{25}$ (QS: al-Nisas: 4: 59) ${ }^{26}$

Dengan pemahaman atas ayat ini, al-Maududi tidak memberikan hak kepada non-Muslim untuk menjadi kepala negara yang memimpin umat Islam. Kedua, ia haruslah seorang laki-laki, syarat ini pun dijelaskan sebagaimana ayat al-Qur'an. ${ }^{27}$ (QS: al-Nisas: $\left.4: 34\right) .{ }^{28}$

Tidak hanya ayat di atas yang menjadi acuan al-Maududi, ia pun mengacu pada ketentuan ha्qdith Rasulullah saw: "Sesungguhnya suatu bangsa tidak akan berkembang jika diperintah oleh seorang wanita". (HR: Bukhari). Ketiga, seorang pemimpin negara haruslah dalam keadaan waras dan dewasa. Syarat ini dijelaskan dalam ayat al-Q ur'å. ${ }^{29}$ (QS: al-Nisał 4: 5). ${ }^{30}$

Keempat, seorang pemimpin negara harus merupakan warga dari negara Islam. Syarat keempat yang diacu oleh al-Maududi berdasarkan keterangan ayat al-Q ur'an. ${ }^{31}$ (QS: al-Anfal: 72). ${ }^{32}$

Dari penjelasan ayat di atas yang kemudian menjadi syarat-syarat yang harus dipenuhi

${ }^{23}$ Muhł̆mmad Abû Zahrah, Aliran Politik dan Aqidah Dalam Islam, Penj. Abd. Rahman Dahlan dan Ahmad Qarib, (J akarta: Logos Publishing House, 1996), 88-104.

${ }^{24}$ Muhł̆mmad A bû Zahrah, Aliran Politik, 105.

${ }^{25}$ Abural-A'lasal-Mawdudi>Tafhîm al-Qur'an (The Meaning of The Qur'an), Vol. vii, 170.

${ }^{26}$ Artinya: "H ai orang-orang yang beriman, taatilah Allah dan taatilah Rasul (Nya), dan ulial-amr di antara kamu. Kemudian jika kamu berlainan pendapat tentang sesuatu, maka kembalikanlah ia kepada Allah (al-Qur'aß) dan Rasul (sunnahnya), jika kamu benar-benar beriman kepada Allah dan hari kemudian. Yang demikian itu lebih utama (bagimu) dan lebih baik akibatnya. (QS: al-N isa\$ 4: 59).

${ }^{27}$ al-MawdudisTafhim al-Q ur'an, 97.

${ }^{28}$ Artinya: “Kaum laki-laki itu adalah pemimpin bagi kaum wanita, oleh karena Allah telah melebihkan sebahagian mereka (laki-laki) atas sebahagian yang lain (wanita), dan karena mereka (laki-laki) telah menafkahkan sebagian dari harta mereka. Sebab itu maka wanita yang saleh, ialah yang taat kepada Allah lagi memelihara diri ketika suaminya tidak ada, oleh karena Allah telah memelihara (mereka). Wanita-wanita yang kamu khawatirkan nusyuznya, maka nasehatilah mereka dan pisahkanlah mereka di tempat tidur mereka, dan pukullah mereka. Kemudian jika mereka mentaatimu, maka janganlah kamu mencari-cari jalan untuk menyusahkannya. Sesungguhnya Allah Maha Tinggi lagi Maha Besar. (QS: al-Nisas: 4: 34).

${ }^{29}$ al-Mawdudi>Tafhim al-Q ur'an, 63.

30Artinya: "Dan janganlah kamu serahkan kepada orang-orang yang belum sempurna akalnya, harta (mereka yang ada dalam kekuasaanmu) yang dijadikan Allâh sebagai pokok kehidupan. Berilah mereka belanja dan pakaian (dari hasil harta itu) dan ucapkanlah kepada mereka kata-kata yang baik. (QS: al-Nisas: 4: 5).

${ }^{31}$ al-Mawdudi>Tafhim al-Q ur'an, Vol. Iv, 149.

${ }^{32}$ Artinya: "Sesungguhnya orang-orang yang beriman dan berhijrah serta berjihad dengan harta dan jiwanya pada jalan Allâh dan orang-orang yang memberikan tempat kediaman dan pertolongan (kepada orang-orang muhajirin), mereka itu satu sama lain lindung-melindungi. Dan (terhadap) orang-orang yang beriman, tetapi belum berhijrah, 
oleh calon pemimpin negara menjadi persyaratan yang menentukan apakah seorang Muslim dapat menjadi kepala negara Islam atau anggota majlis permusyawaratan.

J ika dilakukan analisa atas persyaratan yang diajukan oleh al-Maududi di atas, persyaratan yang keempat ini hampir sama dengan persyaratan nomor pertama di atas, ia tidak memberikan hak kepada warga non-Muslim untuk memimpin negara Islam meskipun ia mempunyai kualitas sebagai seorang pemimpin. J ika kita bandingkan dengan pendapat al-Maududi sebelumnya yang mengatakan bahwa masing-masing manusia mempunyai peluang dan kedudukan yang sama dan tidak ada perbedaan untuk menjadi seorang khalifah di muka bumi ini, terlihat bahwa kata-kata al-Maududi ini tidak konsisten atau bertolak belakang dengan kata-kata sebelumnya.

Di samping syarat-syarat di atas, al-Maududi juga memberikan syarat-syarat seorang pemimpin negara yang harus dipilih dan kriteria yang tidak boleh dipilih dengan merujuk beberapa ayat-ayat al-Q ur'an. Di antara syarat tersebut adalah: bersifat amanat, adil, bertakwa, berilmu luas. Di antara ayat-ayat al-Q ur'an yang menjadi acuan al-Maududi adalah QS: 4 (alNisa), 58; QS: 49 (al-H ujurat), 13; QS: 2 (al-Baqarah), 247; dan QS: 18 (al-Kahf), 28.

Menarik untuk dicermati ketentuan yang ditetapkan oleh al-Maududi perihal syarat-syarat kepala negara tidak dimasukkan keturunan Quraysh sebagai syarat menjadi seorang pemimpin negara meskipun telah jelas dinyatakan dalam h $\not$ dith $\mathrm{Nabi} .{ }^{33}$ Dalam karyanya al-Maududi tidak memberikan alasan mengapa ia tidak mencantumkan syarat kepala negara dari suku Quraysh padahal syarat tersebut telah disepakati oleh mayoritas ulama Sunni> Di sini nampaknya alMaududi menyadari bahwa persyaratan harus dari suku Quraysh sudah tidak realistis lagi di masa modern saat ini. Di samping itu tidak begitu penting untuk diterapkan pada masanya mengingat sudah begitu jauh jarak waktu yang memisahkan. Dengan demikian sangatlah sulit untuk mendeteksi apakah ia betul berasal dari suku Quraysh atau bukan. Alasan lain adalah tidak pastinya di setiap negara termasuk di Pakistan sendiri berada suku Qurysh mengingat saat ini umat Islam tersebar di seluruh dunia bukan hanya di Arab saja. Tambahan lagi mengingat

maka tidak ada kewajiban sedikitpun atasmu melindungi mereka, sebelum mereka berhijrah. (Akan tetapi) jika mereka meminta pertolongan kepadamu dalam (urusan pembelaan) agama, maka kamu wajib memberikan pertolongan kecuali terhadap kaum yang telah ada perjanjian antara kamu dengan mereka. Dan Allah Maha Melihat apa yang kamu kerjakan." (QS: al-Anfal : 72).

${ }^{33}$ Ada beberapa hadits Nabi yang menceritakan tentang keutamaan suku Q uraisy, dan dari hadits Nabi ini kemudian para ulama merumuskan bahwa salah satu syarat seorang imam adalah ia dari suku Quraisy. Di antara hadits itu adalah sebagai berikut: "Dalam masalah ini, manusia selalu menuruti suku Quraisy; yang muslim mengikuti yang muslim, dan yang kafir mengikuti yang kafir" (HR. Bukhari dan Muslim), "Masalah ini selalu berada di tangan suku Q uraisy. Siapa pun yang menentangnya, wajahnya akan ditampar oleh Allah, selama suku Quraisy melaksanakan ajaran Islam' (HR. Bukari). Dari hadits ini kemudian muncul pertanyaan, apakah jabatan seorang pemimpin mesti dijabat oleh orang Quraisy, apakah tidak boleh orang lain?. A pakah hadits itu mengandung makna perintah yang harus dilaksanakan ataukah hanya sekedar berita tentang keutamaan suku Quraisy di bandingkan dengan sukusuku lainnya pada waktu itu?. Kalau kita memahami sejarah Arab saat itu, ada beberapa alasan mengapa suku Quraisy dianggap sebagai suku yang paling utama, yakni suku Quraisy pada waktu Islal lahir telah menempati kedudukan yang terhormat di tanah Arab. Menurut hemat penulis, hadits-hadits yang berisi keutamaan suku Quraisy di atas bukanlah sebuah perintah yang wajib dilaksanakan, akan tetapi sebuah berita tentang keutamaan suku Q uraisy. Hal ini bisa dipahami dari pernyataan “... . selama mereka menegakkan agama Islam”. Hadits di atas bisa dibantah dengan hadits Nabi yag lain "A bu Dzar berkata: kekasihku (Nabi) berwasiat kepadaku agar aku patuh dan taat walau orang yang menjadi pemimpin adalah seorang hamba hitam yang jelek" (HR. B ukhari dan M uslim. Dari hadits ini semakin jelaslah bahwa hadits yang berisi keutamaan suku Quraisy tersebut hanya sebuah cerita, berita atau pemberitahuan dan bukanlah sebuah kewajiban yang mesti diterapkan. 
alasan yang diutarakan oleh Ibn Taymiyah di atas yakni permasalahan keharusan dari suku Quraysh termasuk permasalahan yang masih diperdebatkan. Pemikiran al-Maududi tentang tidak dimasukannya syarat pemimpin harus dari suku Quraysh menjadikan ia seorang intelektual Islam pertama dari kalangan pemikira Islam modern yang secara tegas menolak ketentuan syarat dari suku Quraysh sebagaimana yang dirumuskan oleh para ulama klasik.

Sisi menarik lainnya untuk didiskusikan perihal syarat jenis kelamin yakni harus laki-laki. Dalam kitab suci al-Qur'an sendiri bukankah telah dijelaskan dengan tegas bahwa tidak ada yang lebih baik di mata Allah kecuali mereka yang bertaqwa (laki-laki dan perempuan). Tidak hanya itu, dalam kehidupan politik, sosial, budaya, ekonomi, laki-laki dan perempaun masingmasing memikul tangung jawab sama, bergandengan tangan dan bahu membahu sebagai mitra sejajar. Seperti ditegaskan dalam al-Qur'an: "Dan orang-orang yang beriman, laki-laki dan perempuan, sebagian dari mereka adalah menjadi penolong bagi sebagian yang lain. Mereka menyuruh (mengerjakan) yang baik dan mencegah yang mungkar, mendirikan shalat, menunaikan zakat dan mereka taat kepada Allah dan rasul-Nya. Allah akan merahmati mereka, sungguh Allah Maha Perkasa lagi Maha Bijaksana" (Q.S. al-Taubah: 71).

J ika kita mengacu pada al-Q ur'an, sebutan perempuan (al-nisa'ł dipergunakan sebanyak 57 kali, sama dengan kata rajul atau rijal ${ }^{4}$ atau al-untha yang berpasangan dengan al-dhakar yang disebut 10 kali. ${ }^{35}$ Perimbangan penyebutan ini selintas mengindikasikan, bahwa antara kedua jenis kelamin tersebut, sungguhpun memiliki perbedaan, namun diperlakukan dan diperhatikan secara berimbang dan adil oleh Islam. Kesetaraan (musawah) ini disebut berulang kali secara berdampingan dan berpasang-pasangan dalam al-Qur'an (lihat misalnya Q.S. alGhafir: 40; Q.S. Ali Imran: 195, Q.S. al-Nahl: 97, dan Q.S. al-Ahzab: 35). Bahkan dalam sejumlah ha्qdith, Nabi Muhammad Saw. justru sangat memuliakan dan menghormati perempuan ketimbang laki-laki. Pada saat Nabi ditanya oleh seorang sahabat "Siapa di antara manusia yang paling utama untuk dihormati?" Beliau menjawab, "Ibumu". "Kemudian siapa lagi?", tanya sahabat lagi. "Ibumu," lanjut Nabi lagi. "Siapa lagi?", tanya sahabat ketiga kalinya. "Ibumu," jawab Nabi lagi. "Siapa lagi?", tanya lagi. Nabi pun kemudian menjawab, "Ayahmu" (HR. Bukhari dan Muslim). Dalam hø̣ith lain Nabi juga bersabda, al-J annah tahtzaqdam al-ummahat (Surga itu ada di bawah telapak kaki ibu).

J ika kita merujuk pada sejarah Islam terdapat tokoh perempuan yang berperan sebagai pemimpin, tokoh ulama dan perawi hadith. Di masa Nabi, tercatat ada 1.232 perempuan yang me-nerima dan meriwayatkan hфdith. Bahkan U mmul Mukminin Aisyah r.a., istri Nabi, tercatat sebagai salah satu dari tujuh bendaharawan hadith. Dia meriwayatkan $2.210 \mathrm{~h}$ đitith. Khadijah bint Khuwaylid, istri Nabi yang pertama, dikenal sebagai perempuan yang sukses dalam dunia bisnis. Al-Shifastercatat sebagai perempuan yang ditunjuk Khalifah U mar sebagai manajer pasar di Madinah, sebuah pasar besar di ibukota pada waktu itu. Zainab, istri Nabi, menyamak kulit dan hasilnya disedekahkan. Zainab istri Ibn Mas'ud dan Asma' bint Abu Bakar keluar rumah mencari nafkah untuk keluarga.

${ }^{34}$ Fuad Abd al-Baqi>al-Mu'jam al-M ufahras li-Alfazjal-Q ur'an al-Karim (Beirut: Dasal-Fikr, 1991), 871 dan 384-385. ${ }^{35}$ bid., 118-119. 
Di medan perang, ba-nyak nama sahabat perempuan yang tercatat sebagai pejuang, baik di garis belakang seperti mengobati prajurit yang luka dan menyediakan logistik maupun di garis depan memegang senjata berhadapan dengan lawan. Nusaybah bint Ka'ab ter-catat sebagai perempuan yang memanggul senjata melin-dungi Rasulullah ketika perang Uhud. Al-Rabi“ bint al-Mu'awwid,\}Ummu Sinan, Ummu Sulaym, Ummu Atiyah, dan sekelompok perempuan lain juga beberapa kali ikut turun ke medan laga. Catatan mengenai keberanian mereka dapat kita

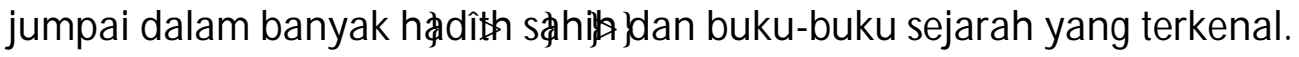

Menarik mengelaborasi lebih lanjut syarat seorang pemimpin negara Islam harus laki-laki dengan argumentasi merujuk pada (QS: al-Nisał. 34). Dalam memahami ayat ini nampaknya pesan substansi ayat ini dengan memahmi sebab-sebab turunnya diabaikan.

Menurut Imam Abu>al-H Asan 'Ali bin Ahmad al-Wahidi (w.468 H), asbab al-nuzulsatau sebab-sebab turun ayat ini bermula dari kisah Sa'ad bin Rabi', seorang pembesar golongan Ansłar dari Madinah, bahwa isterinya, $\mathrm{H}$ abibah bint Zayd bin Abi H urayrah, telah berbuat nushuz (durhaka atau menentang keinginan Sa'ad untuk bersetubuh). Karena perbuatannya itu, ia pun ditampar oleh suaminya. Habibah kemudian mengadukan masalahnya ini kepada Nabi Saw. Nabi kemudian memutuskan untuk men-qisł̧s)(membalas dengan sanksi serupa dengan perbuatannya) terhadap Sa‘ad. Tetapi begitu qisłsjakan dilakukan, Nabi memanggil pasangan suami-istri tersebut seraya mengabarkan ayat yang baru turun melalui J ibril, Nabi kemudian membatalkan perintah qisłasterhadap Sa'ad. ${ }^{36}$ Dari sini dapat dipahami bahwa pemakaian ayat tersebut untuk mengharamkan kepemimpinan perempuan di luar "urusan ranjang" jelas memiliki validitas yang lemah. Ayat tersebut juga bukan berupa kalimat instruksi ('amar), namun hanya bersifat khabariyah (berita), sehingga akurasi soal hukum wajib atau haramnya ternyata kurang efektif. Pelarangan seorang pemimpin perempuan kerap kali didukung dengan argumentasi

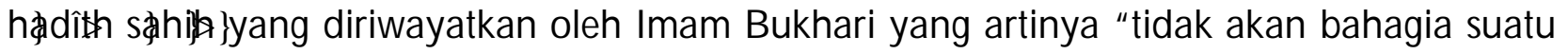
kaum yang menyerahkan urusannya (mengangkat penguasa) kepada seorang perempuan".

Untuk menguji keabsahan pengambilan hukum tersebut, kita tinjau sebab-sebab munculnya hadith ini. Ahmad bin 'Ali bin Hajar al-Asqalani (w. 852 H) dalam karyanya, Fath/al-Baris menyebutkan bahwa hđdth tersebut bermula dari kisah Abd Allah bin Hudhayfah, kurir Rasulullah Saw. yang menyampaikan surat ajakan masuk Islam kepada Kisra Anusyirwan, penguasa Imperium Persia yang beragama Majusi. Ternyata ajakan tersebut ditanggapi sinis dengan merobek-robek surat Nabi. Dari laporan tersebut Nabi Saw. memiliki firasat bahwa Imperium Persia kelak akan terpecah-belah sebagaimana Anusyirwan merobek-robek surat itu. Tidak berapa lama kemudian firasat itu terbukti. Imperium itu jatuh ketika dipimpin puteri Kisra yang bernama Buran. Dari sini muncullah hđdith di atas. Pernyataan Nabi tersebut sangatlah argumentatif, karena kapabilitas Buran yang lemah dalam manajemen kepemimpinan. ${ }^{37}$

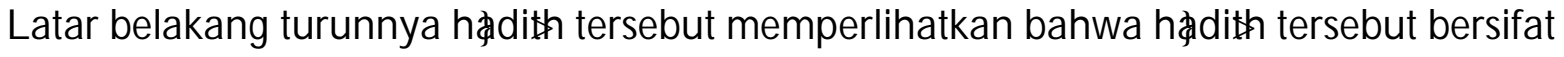
kasuistis dan kondisional. Obyek pembicaraan Nabi bukanlah kepada seluruh perempuan, akan

\footnotetext{
${ }^{36} \mathrm{Abu}$ al-Hasan 'Aliłbin Ahinad al-Wahidi>Asbab al-Nuzul, ed. Sayid Ahmad Shaqr (Kairo: Muassasah Ulumul Qur'an, 1987), 182-183.

${ }^{37} \mathrm{Abu}$ al-Fadl\}Shihab al-Din A hmad bin 'Ali bin Hajar al-'Asqalani, Fath,al-BariSharh,al-Bukhari,vvol. Xiii (Mesir: Mustąfaral-Bab al-H qlabiæwa A wlad, 1959), 55-56.
} 
tetapi hanya tertuju kepada Puteri Anusyirwan yang kredibilitas kepemimpinannya diragukan. Terlebih di tengah percaturan politik Timur Tengah saat itu yang rawan peperangan antar suku dan kerajaan.

Pemahaman ini dikuatkan dengan pendapat Ibn Jarir al-T \$barisyang melegtimasi kepemimpinan perempuan. Demikian pula pendapat sebagian ulama mazhab Maliki, sebagaimana diungkap Ibn $\mathrm{H}$ ajar al-Asqalani. ${ }^{38}$ Dalam lintas sejarah, di bumi Mesir juga pernah muncul seorang penguasa puteri dari Dinasti Mamalik yang bernama ratu Shajaratuddur. Bahkan, jauh sebelum Islam muncul, pada masa Nabi Sulaiman, ada negeri yang diabadikan sebagai salah satu nama surat dalam al-Qur'an yang dikenal baldah tayyibah wa rabb ghafup (negeri yang adil, makmur, aman dan sentosa), yaitu negeri Saba'. Negeri ini ternyata dipimpin oleh penguasa perempuan, Ratu Bilqis.

Ratu Bilqis dikisahkan mampu mendinamisasikan sistem pemerintahan yang demokratis dengan mengoptimalkan dialog terbuka dengan mengikutsertakan para elite politik di negaranya (al-mala'). Begitu pula tatkala menyikapi tawaran (baca: da'wah) Nabi Sulaiman as., Bilqis sangat menghormati pluralisme agama dengan mempertimbangkan secara jernih sampai akhirnya mengikuti kebenaran yang dibawa Nabi Sulaiman as.

J ika kita memperhatikan apa yang diungkapkan oleh para ulama di atas perihal syarat pemimpin negara harus laki-laki dan berupaya mengelaborasi argumentasinya, nampaknya mereka kurang atau bisa dikatakan mengabaikan dalam memahami nilai substansi pesan dari ayat QS: al-Nisa\$ 4: 34 tersebut. Mereka kebanyakan hanya memahami ayat tersebut secara tekstual bahwa laki-laki adalah pemimpin perempuan tidak hanya dalam sudut keluarga melainkan juga dalam memimpin negara dan melupakan pemahaman substansi turunnya ayat tersebut.

\section{Kesimpulan}

Dari uraian di atas prihal teknik pengangkatan seorang pemimpin negara dan syarat-syarat yang harus dimiliki oleh seorang kepala negara sangatlah bervariasi. Ada yang lebih mementingkan faktor kualitas kepemimpinan (kemampuan) tanpa memperdulikan status-nya (laki-laki atau perempuan dan berasal dari suku Quraysh atau bukan); ada juga yang memadukan keduanya (kualitas kepemimpinan dan status).

Perbedaan ini tentunya dipengaruhi oleh latar belakang kondisi sosial di mana mereka hidup, dan yang lebih penting lagi adalah perbedaan pola pemahaman dalam menafsirkan teks-teks suci (al-Q ur'an dan $\mathrm{H}$ ditith) dan teks sejarah. Perbedaan pola penafsiran ini secara otomatis akan mempengaruhi produk pemikiran, tidak terkecuali tentang teknik pengangkatan dan kriteria seorang calon kepala negara.

J ika kita membaca pemikiran-pemikiran di atas, memang ada beberapa pemikiran yang nampaknya sudah tidak realistis jika diterapkan untuk kondisi saat ini. Meskipun begitu, menurut hemat penulis sebagian besar pemikiran tersebut masih tetap relevan jika kita terapkan untuk kondisi saat ini-bahkan sampai kapan pun karena sifatnya abadi; seperti tentang kriteria pemimpin harus adil, berwawasan luas dan sebagainya.

${ }^{38^{\prime} A s q a l a n i, ~ F a t h, a l-B a x i ; 56 . ~}$ 
Meskipun begitu, perbedaan-perbedaan tersebut adalah sebuah rahmat dan hikmah yang tidak harus ditutup-tutupi apalagi disalah-salahkan, karena perbedaan tersebut adalah kekayaan khazanah pemikiran Islam yang tersimpan dalam karya bermutu yang harus dipelihara dan disyukuri sebagai alternatif pilihan dan referensi bagi kita saat ini dan kelak. Wa Allah A"lam.

\section{Daftar Rujukan}

Abiæabi', Ibn. Suluk al-Malik fi đadbipal-Mamalik. Kairo: Dasal-Sha'ab, 1970.

Abu®awud, Abu>Sunan Abu Đawud. Beirut: Mu'assasah al-Kutub al-Thaqafiłah, J il. 1, 1988. AbußZahrah, Muhłmmmad. Aliran Politik dan Aqidah dalam Islam, terj. Abd. Rahman Dahlan dan Ahmad Q arib. J akarta: Logos Publishing House, 1996.

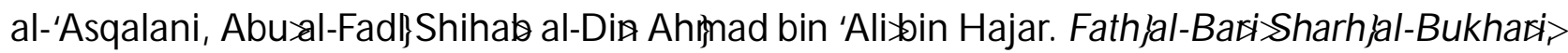
vol. Xiii. Mesir: Mustąa alal-Bab al-H labixwa Awlad, 1959.

al-Baqi>Fuad A bd. al-M u'jam al-M ufahras li-Alfaz,al-Q ur'an al-Karim. Beirut: Dasal-Fikr, 1999. $\mathrm{H}$ anbal, Ahinnad bin. Musnad Ibn Hanbal. Beirut: Dasal-Fikr, J ilid 2, t.t. Ibn Khaldun,.al-Muqaddimah. Beirut: Dasal-Fikr, t.t. Ibn Tayamiyah. al-Siyasah al-Shar'iyah fiłslah al-Ra'y wa al-Ra'łyah. (Beirut: Dasal-Kutub al'Arabiyah, 1966.

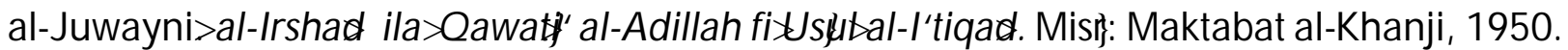
Khan, Qamaruddin. Pemikiran Politik Ibn Taimiyah, penj. Anas Mahyuddin. Bandung: Pustaka, 1983.

Lambton, Ann KS. State and Government in M edieval Islam. London: Oxford U niversity Press, 1981.

al-Maududi, Abu>al-A'la. Tafhim al-Qur'an (The Meaning of The Quran), penj. 'Abd al-'Aziz Kamal. Lahore: Islamic Publications, 1989.

. Abu al-A'la, The Islamic Law and Constitution, Penj. Asep Hikmat. Hukum dan Konstitusi; Sistem Politik Islam. Bandung: Mizan, 1990.

. Politik Alternatif; Suatu Perspektif Islam, Penj. Moh Nurhakim. J akarta: Gema Insani Press, 1991.

al-Mawardi>Abu※ asan. Adab al-Dunyawa al-Din, tah qiø; Abd al-Satar Ahmad Faraj. Beirut: 'Alam Kutub, t.t. . al-Ahkam al-Sultaniyah. Mesir: Matba'ah al-Watan, $1298 \mathrm{H}$.

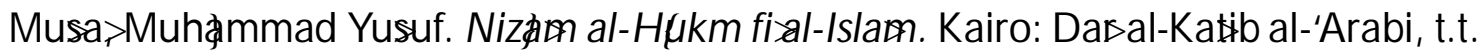

Pulungan, J. Suyuthi. Fiqh Siyasah: Ajaran, Sejarah, dan Pemikiran. J akarta: Raja Grafindo Persada, 1994.

al-Shahrastani>al-Milalwwa al-Nihal: B eirut: Dasal-Fikr, jilid 1, t,t.

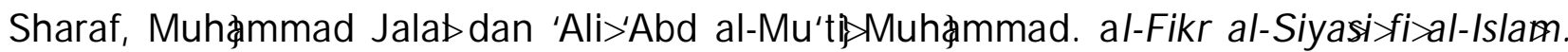
Iskandariyat: Dasal-J ami'ah al-Mistijyah, 1978.

al-Wahidi, Abural-H san 'Aliøin Ahmad. Asbab al-Nuzul(ed). Sayid Ahmad Shaqr, Muassasah 'Ulum al-Qur'an, 1987. 